\title{
The Irish Catholic Church under Charles II: the 'Popish Plot' and the Martyrdom of Oliver Plunkett
}

L'église catholique irlandaise sous Charles II : le 'complot papiste' et le martyre d'Oliver Plunkett

Marie-Claire Considère-Charon

\section{CpenEdition}

\section{Journals}

Electronic version

URL: http://journals.openedition.org/rfcb/3579

DOI: $10.4000 /$ rfcb.3579

ISSN: 2429-4373

Publisher

CRECIB - Centre de recherche et d'études en civilisation britannique

Printed version

Date of publication: 1 March 2013

ISBN: 2-911580-37-0

ISSN: 0248-9015

\section{Electronic reference}

Marie-Claire Considère-Charon, " The Irish Catholic Church under Charles II: the 'Popish Plot' and the Martyrdom of Oliver Plunkett », Revue Française de Civilisation Britannique [Online], XVIII-1 | 2013, Online since 01 March 2013, connection on 22 March 2020. URL : http://journals.openedition.org/rfcb/3579 ; DOI : https://doi.org/10.4000/rfcb.3579

This text was automatically generated on 22 March 2020.

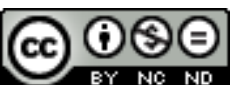

Revue française de civilisation britannique est mis à disposition selon les termes de la licence Creative Commons Attribution - Pas d'Utilisation Commerciale - Pas de Modification 4.0 International. 


\title{
The Irish Catholic Church under Charles II: the 'Popish Plot' and the Martyrdom of Oliver Plunkett
}

\author{
L'église catholique irlandaise sous Charles II : le 'complot papiste' et le martyre \\ d'Oliver Plunkett
}

Marie-Claire Considère-Charon

1 In 1681, Oliver Plunkett, the Roman Catholic Archbishop of Ireland accused of instigating a papist plot against the British monarchy, was found guilty of high treason and duly sentenced to be hung, drawn, quartered and beheaded at Tyburn. The sentence was carried out on July 1 according to the ancient calendar, that is to say on July 11 1681. Plunkett's body now lies in Downside Abbey. His head is kept in Saint Peter's church in Drogheda where, each year, thousands of pilgrims come to pay homage to his memory. His feast is celebrated on the first Sunday in July, the day on which Orange Order parades take place all over Northern Ireland. Demonised by the English Parliament, and later declared innocent of the charges laid against him, Oliver Plunkett was beatified by Pope Benedict XV in 1920 and canonised in 1975 by Pope Paul VI. And yet, curiously enough, for a long time the figure of this saint remained a subject of controversy among Irish Catholics, the devotion of some being only equalled by the somewhat hostile reserve of others.

2 This rather puzzling situation leads one to suppose that Plunkett's death is more than just another tragic episode in the history of the persecution of Irish Catholics and that it is infinitely more complex than the way it is presented in hagiographical narratives. Without going so far as to attempt to deconstruct them ${ }^{1}$, it is necessary to account for an exceptional destiny in given historical circumstances. The questions we are led to ask concerning the supposed plot and the death of Oliver Plunkett can bring into play two approaches which are different but complementary. The historical approach enables us to understand how the prime representative of the Catholic Church in Ireland met his destiny at a time when the history of Ireland and that of England were inextricably interwoven. The anthropological perspective throws light on the 
martyrdom of Oliver Plunkett by proposing an explanation grounded in the voluntary choice of death for one's faith. It also makes it possible to explain why the role of that high dignitary of the Catholic Church in Ireland was contested for so long within his own community of believers.

\section{A dangerous mission}

3 At the beginning of the reign of Charles II of England, religious life in Ireland was in a state of chaos and conflict. The consequences of Cromwell's years in power were felt not only among the faithful but just as much within the clergy. The bishops had lost all their authority and the Catholic Church of Ireland was like a ship with no-one at the helm. Under the penal laws, masses were forbidden, and those celebrated in secret took place in old quarries, abandoned houses, or disused hill forts. ${ }^{2}$ Religious persecution had obliged priests to go into hiding. Many of them, fearful of being recognised, lived among lay inhabitants and refused to comply with any form of authority. They often took sides with the mass of peasants who had been dispossessed of their land and who lived by plunder, engaging in a kind of guerrilla warfare against the English occupiers. They moved around the country in groups, terrorising the population. These outlaws were called 'rapperees', or even 'tories', derogative terms suggesting immoral behaviour and dishonest practices.

4 After being ordained bishop in 1669, Oliver Plunkett, who had asked to remain in Rome in order to escape the persecutions under Cromwell, was appointed Archbishop of Armagh and Primate of Ireland, a position that he held for twelve years. The mission entrusted to him by the papal authorities was to restore order to the Irish Catholic Church and to set right the abuses and deviations resulting from Cromwellian repression. However, this mission intended to 'revive hope in the people of Ulster in these times of trial' was to encounter a great many difficulties and obstacles which he had undoubtedly not foreseen. Although he was fluent in Gaelic and English, after twentythree years spent in Rome, Oliver Plunkett was a stranger in his own country. This aristocrat, ${ }^{3}$ who belonged to an influential Anglo-Norman family of royalist sympathies, had been educated by Jesuits at the Irish college in Rome and was highly cultured. In County Louth, most members of the clergy were illiterate and found it difficult to accept the authority of a native of County Meath, all the more so as he belonged to the Anglo-Irish nobility and seemed to be closer to the English authorities than to the Irishborn people.

5 As soon as he arrived in Ireland, Oliver Plunkett threw all his energy into carrying out his mission successfully. In 1670, he convened an episcopal conference in Dublin and organised a number of synods in his archdiocese. It is said that owing to his tireless activity he confirmed 48,655 people during the first four years of his ministry. He undertook to have schools built for young Catholics and for the clergy, whose lack of theological knowledge he deplored. The school he founded in Drogheda, with the help of two Jesuits, was to take in young Catholics and children from prominent Protestant families. He also wished to be seen as a unifying figure, and with this aim in mind, he applied himself to saving the souls of those of his compatriots whose lives were given over to alcoholism and debauchery. He had also attempted to bring the tories back into the fold by acting as an intermediary between the outlaws and the English authorities, and succeeded in saving some of them from the death penalty on condition that they 
left the country. His missionary zeal, however, did not make him friends only. His forceful manner, his reforming spirit and his unbounded activity eventually aroused discontent and anger among the friars and many priests, who accused him of simony and of being suspiciously sympathetic towards Protestant notables. Some went as far as to say that he was an agent working for the English. Moreover, a difference in opinion existed between Plunkett and the Archbishop of Dublin, Peter Talbot, concerning the precedence of the archbishopric of Armagh over that of Dublin. During the synod held in Dublin in June 1670, a quarrel broke out between the two prelates. The question arose as to which of them should chair the meeting. Oliver Plunkett declared that he held his authority from the pope; Talbot retaliated that the king of England had appointed him head of the Irish Catholic hierarchy in civil matters. ${ }^{4}$

6 In one of his letters, Oliver Plunkett expressed his surprise at the marked hostility of the Irish clergy to all authority emanating from the pope, referred to by the Latin term praemunire. ${ }^{5}$ This tradition of independence, consisting, as it were, in establishing the precedence of the Church of Ireland over the Roman Catholic Church, may surprise present-day Irish Catholics just as much as it shocked the new archbishop at the time, but it remains dear to the hearts of Irish Anglicans. They base their conviction on the example of Saint Patrick who apparently did not receive his evangelising mission from Rome, but acted on his own personal initiative, free from all allegiance. P. Blanshard gives the following account of this conviction:

Saint Patrick, they contend, was not a Roman partisan at all. They argue that in his famous confessions he did not make one verbal gesture of loyalty toward papal power. He functioned in Ireland long before any great division in the early church and he landed on Irish shores in A.D.432 before the Roman bishops had won universal recognition. He was a prepapal Christian. ${ }^{6}$

7 If he appeared to be commissioned by the pope to watch over the destiny of a clergy used to a great deal of liberty, the new archbishop moreover embodied secular power in a country with a strong monastic tradition. Soon after his arrival in Ireland, he had to take a stand to settle the disputes ${ }^{7}$ between the Dominicans and the Franciscans. ${ }^{8}$ Three monasteries deserted by the Dominicans during the Cromwellian period had been taken over by the Franciscans. ${ }^{9}$ Even if they belonged to the Dominicans by right, the Franciscans, who had held firm during the most turbulent times under Cromwell, did not intend to give them up and were supported by the vast majority of the people. Oliver Plunkett took sides with the Dominicans and in doing so lost the support of the Franciscan community, which was well-established and highly appreciated in Ireland. The news spread to Rome, where two Franciscan seminarists broke the head off a bust of Plunkett at Saint Isidore's College. ${ }^{10}$

\section{The crisis of the State in England}

Even if religious repression arose essentially from the antagonism between the English Protestant authorities in power and the heterodoxy embodied by the Catholic Church of Ireland, the rhythm of repressive practices would vary according to the options open to the sovereign and the punitive position of the English Parliament. The Cromwellian period had been marked by a wave of unparalleled repression against Catholics. There followed a brief period of respite at the beginning of the reign of Charles II (1660-1685), due to the sovereign's benevolence towards them, and consequently a relaxing in the application of the penal laws. Oliver Plunkett, newly appointed Archbishop and Primate 
of Ireland, would take advantage of circumstances favourable to the re-founding of his Church. In 1672, Charles II had issued a Declaration of Indulgence suspending all penal laws against Roman Catholics and Protestant Nonconformists. But the latter, who considered themselves Protestants above all, were opposed to any measure that would emancipate Catholics, and Parliament had strongly objected to Charles's initiative.

During the late 1670s, as doctrinal allegiances had become more rigid and a barely concealed rivalry was growing between the king and Parliament, a genuine crisis occurred concerning the legitimacy of the monarch's power in England. As Supreme Head of the Church of England, the king was intended to bind together the Body Religious and the Body Politic, and to unify his subjects' bodies and souls. Through his royal prerogative, he was the guarantor of religious orthodoxy and the safety of the State. However, King Charles II, ${ }^{11}$ who had spent a long time in France and was married to a Portuguese Catholic princess, ${ }^{12}$ had difficulty in concealing his sympathies for France, where the agreement between the sovereign and the Roman Church made the former all-powerful. The new English king, in spite of the pressures exerted on him by his mother and his sister Henrietta, both Catholics, had been careful not to become a convert and thus compromise his throne. The memory of his long exile and of the Puritan passions unleashed under Cromwell obliged him to act prudently. But Parliament was not taken in, and, through the edicts of persecution, set about reinforcing its authority on religious matters, at the same time seeking to confound the monarch.

The Chancellor, Lord Clarendon, who had arranged the king's marriage to the Princess of Braganza, had been replaced by a group of confidants called by their adversaries 'the Cabal', incidentally a word composed of the initials of their names - Clifford, Arlington, Buckingham, Ashley and Lauderley. Convinced as they were that religious unity was necessary to national unity, ${ }^{13}$ they openly stood out against the king and, in 1673 , imposed the Test Act on him. This repressive law excluded from any public office all those who did not swear an oath of loyalty to the king. It made it compulsory for all Crown officials to declare themselves against transubstantiation and to receive the Eucharist according to the Anglican rite. The new viceroy of Ireland, the earl of Essex, then ordered the closing of all Catholic schools and religious institutions. The discovery in 1673 that the king's own brother had converted to Catholicism ${ }^{14}$ was to spark further hostilities from Parliament, suspecting that the king himself had secretly become a Catholic. The penal laws were re-enforced and sent the Irish Catholic clergy into exile or clandestinity. However, those who sought proofs against the king failed to find any, insofar as he regularly attended Anglican services. ${ }^{15}$

11 A motion passed by Parliament in 1673 ordered all the bishops and regular clergy of the Irish Catholic Church to leave the kingdom. Oliver Plunkett refused to obey and opted for clandestinity. He then began a life of wandering, disguising his identity under various assumed names. In a letter ${ }^{16}$ dated December 15 1673, he explained his sense of duty and his deep sadness at the closing of the schools for young Catholics:

We would rather die from hunger and cold than abandon our flocks. It would be a shame if spiritual soldiers reared and trained in Rome should become hirelings. The thing that has caused me the greatest sorrow is to see the destruction of the schools I founded, after so much hard work had gone into them. We have so many talented young Catholics: what are we to do now? ${ }^{17}$ beginning of the $16^{\text {th }}$ century had been to ensure liaison between Parliament and the 
king, was in a way a State within the State..$^{18}$ Composed of thirty or so members, it was headed by Shaftesbury, Sir William Temple, Lord Russell and Halifax. ${ }^{19}$ Shaftesbury, a sworn enemy of the king, was the instigator of the 'Popish Plot' which ended in the putting to death of Oliver Plunkett. By making the king sign the prelate's death warrant against his inclination, Shaftesbury hoped that he might trick him into betraying his favourable leanings towards Catholics.

\section{The 'Popish Plot'}

13 In 1678, a former Anglican minister, Titus Oates by name, who had converted to Catholicism more out of interest than conviction, announced that he had discovered a Catholic plot against the king. Oates had lived for a time in a Jesuit community at SaintOmer, from which he had been expelled. His bitterness had led him to concoct a plan to denounce the Jesuits, whom he accused of hatching a plot to set fire to the City, ${ }^{20}$ assassinate the king and replace him with his brother, a recent convert to Catholicism who, once in power, would massacre Protestants. This announcement was just what Parliament needed, and it considerably increased the Catholics' unpopularity. It stirred up feelings of hatred of popery and fear of France. As a wave of collective hysteria swept over the population, eighty-four Catholics were immediately arrested and accused of taking part in the plot. Some of them were executed before it was proved that Titus Oates had lied. The 1679 elections were won by the Whigs (supporters of Parliament), ${ }^{21}$ who had used the rumoured Titus Oates plot as their principal electoral argument.

14 On December 6 1679, Oliver Plunkett, hounded by various factions, was arrested and imprisoned in Dublin Castle for six weeks for rallying 70,000 Catholics to the cause of re-establishing 'Roman law' in Ireland. His trial was first held in Ireland, at Dundalk, where none of the Protestant jurors were willing to find him guilty on the testimony of two defrocked Franciscans, John McMoyer and Edmund Murphy. Shaftesbury, fully aware that Plunkett would never be sentenced in Ireland, had him transferred to Newgate prison in London, in spite of the intervention of the earl of Essex, the king's viceroy in Ireland, who protested the innocence of Plunkett. ${ }^{22}$ At the first trial held in London, no sentence could be passed. It was followed by a second one resulting in Plunkett being sentenced to death. In the case of crimes of high treason, all the customary judicial procedure could be circumvented by order of the king. But Charles II, who had been unable to find any means of preventing Parliament from passing a series of repressive edicts against Catholics, did not intervene either to save the archbishop.

\section{From the demonisation to the martyrdom of Oliver Plunkett}

15 As Michel Foucault explains, a society defines itself by what it excludes. But the demonisation of the Other only serves to reject a possible identification with, or a recognition of the Other which, in the words of the philosopher Emmanuel Lévinas, " supports in return the belonging to humankind'23. Parliament's objective was to make Oliver Plunkett appear to be an obstinate, arrogant and seditious heretic. If the scaffold was 
deemed appropriate to punish the crime of sedition, quartering was the fate deserved by a demonic body. The punishment was considered as a dissuasive warning, and execution aimed to edify the public and prevent political disorder. The English State, embodied by Shaftesbury, which based its decisions on the official Church, put to death one of the highest representatives of another Church, thus fulfilling its mission as a purifying authority. Even though the condemned man inevitably faced death, he could still save his soul if he admitted his guilt during the proceedings. In the case of the death penalty, the judge would encourage the heretic to embrace the 'true faith'. But, following the example of all martyrs, Oliver Plunkett preferred to suffer the pain of death rather than deny his faith. He chose the sacrifice made by the Son of God over submission to the State. Celtic monks usually distinguished between three kinds of martyr: the white martyr, the one of chastity, referring not only to physical purity, but also to the purity of the heart, as well as to the refusal to give in to the temptation of worldly goods; the red martyr, who sheds his blood as a disciple of Christ; and the green martyr, whose life is given over to daily struggle. In the eyes of the Irish Catholics, the sacrifice ${ }^{24}$ of Oliver Plunkett would be the embodiment of all three, and his reaction to the cruel tortures inflicted on him, a means of identifying the supernatural signs of the martyr.

\section{Martyrdom: representation and memory}

16 What meaning can the martyr perceive in the ordeal he undergoes? According to Jean Bodin's demonology, ${ }^{25}$ Man is the noblest of God's creations because the nature of his being is both terrestrial and supernatural. He is thus a medial creature who can leave aside the mortal part of his body in order to converse with the divine. He partakes of angels. Even if the temporal authority considers the martyr as a figure of the Devil, the pains of his torture are a sign of the unity between man and God through the figure of Christ. During the passage from life to death, the victim is no longer aware of himself as such. His body may be abandoned to his executioner, but his spirit is inhabited by God. In giving himself up to God, he witnesses his adoption by Christ. The violence which has killed the martyr obviously reduces him to a physical nonentity, but his union with Christ places him above everything and everyone, and gives him immortality. In an official letter to the Society for the Propagation of the Faith, Dr Brennan, ${ }^{26}$ who was Archbishop of Cashel, then of Waterford, affirmed the deep feelings of edification and admiration among all those who were present at Plunkett's execution: 'Because he displayed such a serenity of countenance, such a tranquility of mind and elevation of soul, [...] he seemed rather a spouse hastening to the nuptial feast, than a culprit led forth to the scaffold'. During his imprisonment in Newgate, Oliver Plunkett had shown that he endured his sufferings with an exemplary serenity and equanimity. According to an eye-witness, the speech he pronounced from the scaffold was worthy of an apostle or a martyr, as if ' the fettering of his body was the freeing of his spirit. ${ }^{27}$

Martyrdom becomes a cultural representation which can only exist if it is borne and perpetuated by the community. All cultural representation is a mental one based on the memory of the collective imagination of a people. It is transmitted by public representations, texts, images ${ }^{28}$ and relics. If the martyrdom embodies a political culture of disobedience towards the authority in power, it goes beyond a mere transgression of the rules of the State. Voluntary choice of death is an act of violence, 
expressing the negation of one's own body as well as that of a perverted political and social order. But the reception of martyrdom varies according to the historical situation and the sensibilities of the members of the community.

Even if this travesty of a trial seriously undermined the idea of justice in England, ${ }^{29}$ Oliver Plunkett's ordeal did not produce the expected effect in Ireland, and the memory of this figure and the role he was called on to play would be the subject of a great deal of debate. Three centuries elapsed between oliver Plunkett's martyrdom and his canonisation for his faith. The controversy which surrounded him until the $20^{\text {th }}$ century is a sign of the ambivalence of his personality and his religious leanings as well as of the blurring of usual points of reference. The fact that he did not really appear to identify with the Irish Catholic community goes some way towards explaining why part of that community continued to reject him for so long.

\section{Conclusion}

The conflict marking the history of Ireland was fuelled by a determination to eradicate not so much the heretic Other in person as the Church to which that heretic Other belonged. The Catholic community as such was not seen as an enemy, but its Church was perceived as a threat, an idea reinforced by the suspicion of a conspiracy between the Catholic Church of Ireland and the great Catholic power that was France. The religious persecution of which Oliver Plunkett was a victim became an integral part of a power struggle between the English sovereign and a force of opposition composed of Parliament and the King's Privy Council. Also to be recalled in this respect is the role of the Irish clergy who did not accept the fact that their Church should be taken in hand by an aristocrat whom they judged to be haughty and distant. The canonisation of Oliver Plunkett, who had been branded as a heretic by the English authorities, took on a double symbolic meaning. As well as being the homage paid to his saintliness as a person, it was also the recognition of the persecutions endured by the Irish people during the $16^{\text {th }}$ and $17^{\text {th }}$ centuries. The aim of this decision was to clear the name of the person by sweeping aside the reservations of part of the Catholic community towards a prelate who, through his missionary zeal and his cultural heritage, had made enemies of many of his compatriots and coreligionists at all levels of society. The Vatican intended him to be perceived as a peace-maker at a time when Irish society had once more fallen prey to its old demons, those of division and fragmentation. Oliver Plunkett, the first Irishman to be canonised after a long period of seven centuries, was to be the last in the line of Irish Catholic martyrs.

\section{NOTES}

1. For the hagiographical sources, see, for instance, L'Osservatore Romano, October $231975, \mathrm{n}^{\circ} 44$; La Documentation catholique, December 9 1975, n 1668, p. 911; Tomás Ó FIAICH, 'Canonisation of St. Oliver Plunkett', Armagh Diocesan Historical Society, vol. 8, n 1, 1975/1976, pp. 181-189. 
2. The penal laws were imposed by the British authorities on Irish Roman Catholics during the 1600's and 1700's in a bid to force people to accept the reformed Christian faith. One of the major restrictions was the ban on the celebration of the Catholic Mass, which meant that Catholic priests and worshippers had to hide in the countryside.

3. On his father's side, he descended from the earls of Fingal, and on his mother's, from the earls of Roscommon. He was also related to the famous Oliver Plunkett, Baron of Louth, and a leading dignitary of the diocese of Armagh.

4. Peter Talbot, who claimed to be very close to King Charles II, had been appointed Archbishop of Dublin in 1669.

5. See Desmond FORRISTAL, Oliver Plunkett in His Own Words, Dublin: Veritas, 1975, p. 22. Praemunire, which means to forewarn or to admonish, consists in 'summoning to court a person accused of asserting or maintaining papal jurisdiction in England' (The Shorter Oxford English Dictionary on Historical Principles, Oxford: Clarendon Press, 1973).

6. Paul BLANSHARD, The Irish and Catholic Power, London: Derek Vershoyle, 1954, p. 37.

7. Cromwell had had to arbitrate the decision about which order should have the use of which monastery.

8. Saint Dominic and Saint Francis were contemporaries; their orders quickly became rivals.

9. The monasteries of Carlingford, Guala (near Enniskillen), and Newtown (in County Down).

10. These Franciscans were John McMoyler and Hugh Duffy, who were to gain the support of a parish priest, Edmund Murphy, who, a short time before, had been suspended from his office by the archbishop for his part in giving credibility to the plot concocted by Titus Oates.

11. In 1670, Charles II and Louis XIV signed the Treaty of Dover (also known as the Treaty of Madame, as it was negotiated with the help of Henrietta of England, the French king's sister-inlaw), in which Louis XIV undertook to pay the English monarch an annual subsidy. He The French king promised to pay Charles an extra sum of money when the latter announced to his subjects his conversion to Catholicism. Louis XIV also pledged himself to send him 6.000 troops if the English people revolted against him. As for Charles II, he agreed to help the French in their fight against the Dutch. He also promised to take every possible step to bring to an end the persecution of the Catholics. The Treaty of Dover remained secret until Charles II tried to persuade Parliament to show more sympathy towards the French authorities. He had succeeded in rallying a number of MPs thanks to part of the sums of money that had been allotted to him by Louis XIV. Those MPs who supported the pro-Catholic sympathies of Charles II were called 'Tories' by their adversaries in Parliament.

12. At the time there was no princess of royal blood and high enough rank who was also a Protestant. The German principalities could offer no heiresses of sufficiently high status.

13. $90 \%$ of English people were Protestants.

14. A search carried out at the home of the Duke of York, the king's brother, had led to the discovery of correspondence between James II and Père La Chaise, Louis XIV's confessor, which was to worsen even further the disagreement between the king and Parliament.

15. Except for the recognition of a superior authority in the person of the pope, there are few differences between the two faiths, and at the time, it would have been difficult to distinguish a high Church Anglican service from a Catholic one.

16. FORRISTAL, op.cit., p.76

17. Quoted in FORRISTAL, op.cit., p. 55.

18. Thomas More, who was beheaded for refusing to recognise Henry VIII as Supreme Head of the Church of England, had been sentenced to death in 1534 by the Privy Council established by Cardinal Wolsey in the early years of the $16^{\text {th }}$ century.

19. Its greatest achievement was the law of habeas corpus (1679), which allowed any imprisoned Englishman, except in cases of treason, to appear before a court within a period not exceeding twenty days. 
20. It is easy to understand the terrorised reaction of Londoners who had known the Gunpowder Plot in 1605, the Great Plague which had devastated London in 1665, and the Great Fire of London, often blamed on the Jesuits, in 1666.

21. 'Whig' is an abbreviation of 'Whigamore', a term used to designate the Puritan peasants in western Scotland. It would first be applied to Dissenters and London merchants. As for the word " Tory', it was a term of abuse used by Whigs to designate one who was attached to the sovereign and to landed property.

22. Tomás Ó FIACH \& Desmond FORRISTAL, Oliver Plunkett: His Life and Letters, Dublin: Appletree, 1975.

23. Emmanuel LÉVINAS, Autrement qu'être ou au-delà de l'essence [1974], Paris : Librairie générale française (Le Livre de poche), 1990, p.138. For Lévinas, the encounter with another is a phenomenon in which the other person's proximity and distance are both strongly felt. The Other can only reveal himself in his true essence by acknowledging, in his turn, a common sense of belonging to the human condition.

24. To sacrifice in its etymological sense: to render sacred.

25. Jean BODIN, De la Démonomanie des sorciers, Paris : Gutenberg reprints, 1979, p.107.

26. Quoted in FORRISTAL, op.cit., p. 93.

27. Alice CURTAYNE, The Trial of Oliver Plunkett, London: Sheed \& Ward, 1953.

28. Dan SPERBER, La Contagion des idées. Théorie naturelle de la culture, Paris : Éditions Odile Jacob, 1996, p. 40.

29. On the day following the execution, the plot disintegrated as rapidly as it had been formed. Shaftesbury, the main instigator of the persecution, was imprisoned in the Tower of London, and Titus Oates, condemned to the galleys.

\section{ABSTRACTS}

The late 1670s under Charles II were a special time in British history during which religious controversy ran high. The rivalry between the king, who issued a Declaration of Indulgence suspending all laws punishing Roman Catholics and other religious dissenters, and a strongly Anglican Parliament had reached its peak. In Ireland the Catholic Church had slowly been recovering from the Cromwellian persecution when Pope Clement IX decided to appoint Oliver Plunkett as Archbishop of Armagh. His mission was to rebuild and reform the Catholic Church in Ireland. Fears of a return to Catholicism in England were exacerbated by allegations by Titus Oates of a 'Popish Plot' to murder Charles II and establish absolutist, Catholic government under James, Duke of York and the king's brother. Oliver Plunkett, after a blatant miscarriage of justice, was executed for high treason. He was beatified in 1920 and canonized in 1975 under Pope Paul VI. Without going so far as to deconstruct hagiographical narratives, which made Plunkett the Irish Church's most celebrated martyr, this article focuses on the political and religious stakes during a troubled period when the destinies of the English and Irish nations and their Churches were not yet clearly mapped.

La fin des années 1670, sous le règne de Charles II, fut marquée par de sérieuses controverses politiques et confessionnelles. Une sourde rivalité opposait le roi d'Angleterre, qui avait promulgué une Déclaration d'Indulgence suspendant les mesures à l'encontre des catholiques et des protestants non-conformistes, et le Parlement anglais très attaché à l'anglicanisme. Au 
moment où l'Irlande se remettait lentement des persécutions de l'époque de Cromwell, le pape Clément IX chargeait le nouvel archevêque d'Armagh, Oliver Plunkett, de reconstruire et de réorganiser l'Église catholique. La crainte d'un retour au catholicisme en Angleterre fut exacerbée par les allégations d'un certain Titus Oates selon lesquelles Oliver Plunkett aurait fomenté un 'Complot Papiste' contre la monarchie britannique. Condamné pour haute trahison, il fut, selon la règle, pendu, éviscéré, écartelé et décapité en 1681. Il fallut attendre 1920 pour qu'il soit béatifié, et 1975 pour qu'il soit canonisé par le pape Paul VI. Sans déconstruire radicalement l'hagiographie, cet article se propose de rendre compte des enjeux politico-religieux à une époque troublée où les destinées des nations anglaise et irlandaise, et de leurs Églises, n'étaient pas encore clairement tracées.

\section{AUTHOR}

\section{MARIE-CLAIRE CONSIDÈRE-CHARON}

Université de Franche-Comté 